\title{
Improving Hepatitis C Screening Rates in an Ambulatory Clinic: an Observational Study
}

Rajesh Essrani, $M D^{7}{ }^{1}$, Eric Nellis, $M D^{2}$, and Hiral Shah, $M D^{2}$

'Department of Internal Medicine, Lehigh Valley Health Network, Danville, PA, USA; ${ }^{2}$ Division of Gastroenterology, Lehigh Valley Health Network, Allentown, PA, USA.

KEY WORDS: Hepatitis C Virus; Liver disease; the Centers for Disease Control; and the United States Preventive Services Task Force.

J Gen Intern Med 35(5): 1610-11

DOI: $10.1007 / \mathrm{s} 11606-019-05363-2$

(C) Society of General Internal Medicine 2020

\section{INTRODUCTION}

Hepatitis $\mathrm{C}$ virus $(\mathrm{HCV})$ is a liver disease that can progress to hepatic fibrosis, cirrhosis, and hepatocellular carcinoma. Risk factors for HCV include people born between 1945 and 1965, hemodialysis, history of Intravenous drug abuse (IVDA), persistent elevation in alanine transaminase without a known cause, human immunodeficiency virus (HIV) infection, and patients who received clotting factors before 1987 or blood products before 1992. Therefore, the CDC and USPSTF recommends HCV screening for all those born between 1945 and 1965 (the baby boomer population) and those with other risk factors. ${ }^{1,2}$

An internal review demonstrated that hepatitis C screening was not routinely or adequately offered at our clinic, an academic practice based in Allentown, Pennsylvania that consists of internal medicine residents and four faculty physicians.

Our goal was to increase HCV screening in baby boomers and assess provider knowledge about HCV screening.

\section{METHODS}

The baseline screening rate over one year was obtained from medical records. All providers were questioned about hepatitis $\mathrm{C}$ screening guideline recommendations, their comfort with screening guideline recommendations, and barriers to screening. After obtaining baseline reports all residents, attending physicians, and clinical staffs were educated on CDC and USPSTF guidelines of HCV screening on baby boomers through lectures, email reminders, and monthly meetings. Patients were educated about HCV screening indications during a routine office visit.

Prior Presentation It was submitted as a poster in ACG conference.

Received July 25, 2019

Accepted September 12, 2019

Published online February 3, 2020
HCV screening test was performed on all patients born between 1945 and 1965 with an unknown HCV status who had no previous HCV antibody testing in the electronic medical record. If the test was positive, then patients were called and informed about the result and referred to hepatitis care clinic for further work up.

\section{RESULTS}

The baseline screening rate was $3.0 \%$. We found that $56 \%$ of providers were unsure who is eligible for screening. The majority (60\%) mentioned not remembering to discuss screening, and only $12 \%$ felt very confident with their understanding of the guidelines. All providers cited they would screen more patients if there were a screening prompt.

We screened 300 patients, and ten patients had a positive HCV screening test (3.3\%). Only two patients had a positive viral load (20.0\%). Five out of 10 positive HCV positive patients had an intravenous drug abuse history $(50.0 \%)$. No patients had undergone previous treatment for $\mathrm{HCV}$ infection.

\section{DISCUSSION}

Roughly $50 \%$ of patients with chronic HCV infection are unaware of their diagnosis. ${ }^{3}$ Regular preventive screening can diagnose 800,000 unknown cases of HCV with the prevention of 120,000 death with proper treatment. Previous studies suggest that HCV screening can be increased by regular education, email reminders, monthly meetings, conferences, posting informational posters and automatically triggering reminders via electronic medical records. ${ }^{4}$

Study limitations include the single site, small sample size and short study duration. We found that baseline screening rates were low, and that inadequate knowledge about screening indications was common. When universal screening was implemented, 2 out of 300 patients had active HCV infection, consistent with findings that baby boomers are at high risk of $\mathrm{HCV}$ infection. 
Corresponding Author: Rajesh Essrani, MD; Department of Internal Medicine, Lehigh Valley Health Network, Allentown 140 Cortland Drive, Danville, PA 17821, USA (e-mail: raj1_essrani@hotmail.com).

Financial Disclosure or Funding This project received no external funding.

\section{Compliance with Ethical Standards:}

Conflict of Interest: The authors declare no conflict of interest.

Informed Consent: Yes. It was obtained.

No IRB approval needed.

\section{REFERENCES}

1. Smith BD, Morgan RL, Beckett GA, Falck-Ytter Y, Holtzman D, Teo CG, Jewett A, Baack B, Rein DB, Patel N, Alter M, Yartel A, Ward JW, Centers for Disease C, Prevention: Recommendations for the identification of chronic hepatitis C virus infection among persons born during 1945-
1965. MMWR Recommendations and reports : Morbidity and mortality weekly report Recommendations and reports. 2012, 61:1-32.

2. Moyer VA: Screening for hepatitis C virus infection in adults: U.S. Preventive Services Task Force recommendation statement. Annals of internal medicine. 2013, 159:349-357. https://doi.org/10.7326/00034819-159-5-201309030-00672

3. Spradling PR, Rupp L, Moorman AC, Lu M, Teshale EH, Gordon SC, Nakasato C, Boscarino JA, Henkle EM, Nerenz DR, Denniston MM, Holmberg SD: Hepatitis B and C virus infection among 1.2 million persons with access to care: factors associated with testing and infection prevalence. Clinical infectious diseases : an official publication of the Infectious Diseases Society of America. 2012, 55:1047-1055. https://doi.org/10. 1093/cid/cis616

4. Sidlow R, Msaouel P: Improving Hepatitis C Virus Screening Rates in Primary Care: A Targeted Intervention Using the Electronic Health Record. Journal for healthcare quality : official publication of the National Association for Healthcare Quality. 2015, 37:319-323. https://doi.org/ $10.1097 /$ jhq.0000000000000010

Publisher's Note Springer Nature remains neutral with regard to jurisdictional claims in published maps and institutional affiliations. 